\title{
Cumulative Carbon Fluxes Due to Selective Logging in Southeast Asia
}

\author{
Vathana Khun ${ }^{1,2}$, Nophea Sasaki ${ }^{1,3}$ \\ ${ }^{1}$ Graduate School of Applied Informatics, University of Hyogo, Kobe, Japan \\ ${ }^{2}$ National REDD+ Taskforce Secretariat, Forestry Administration, Phnom Penh, Cambodia \\ ${ }^{3}$ School of Earth and Environmental Sciences, University of Adelaide, Adelaide, Australia \\ Email: vathana.khun@gmail.com, nophea.sasaki@adelaide.edu.au
}

Received 24 September 2014; revised 20 October 2014; accepted 15 November 2014

Copyright (C) 2014 by authors and Scientific Research Publishing Inc.

This work is licensed under the Creative Commons Attribution International License (CC BY). http://creativecommons.org/licenses/by/4.0/

(c) (i) Open Access

\begin{abstract}
Selective logging creates a large amount of wood residues in forests in addition to producing a small amount of sawnwood for use as source of construction materials. Although accounting for carbon fluxes in harvested wood products (HWPs) becomes necessary in the fight against climate change, previous studies focused mainly on carbon fluxes in HWPs in temperate and boreal forests. This report attempts to analyze carbon fluxes in various wood components created by selective logging in production forest in Southeast Asia during a hypothetical period of carbon project implementation between 2015 and 2050 under conventional (CVL) and reduced-impact logging (RIL). Study results suggest that CVL produced about $146.6( \pm 5.4)$ million $\mathrm{m}^{3}$ annually. Logging created annual carbon fluxes of about $0.23,0.23,0.20,0.69$, and $0.15 \mathrm{MgC} \mathrm{ha}^{-1} \cdot \mathrm{year}^{-1}$ in sawnwood, wood wastes at sawmills (SWW), wood product wastes due to logging damages remained in the forests (WPW), branches and top logs (BRA), and belowground dead root (BLD), respectively. Cumulative carbon fluxes were estimated at 281.0, 506.6, and 87.4 $\mathrm{TgC}_{\text {year }}^{-1}$ in sawnwood, onsite (WPW, BRA, BLD), and offsite (SWW) pools, respectively. Except in SW, cumulative carbon fluxes in onsite and offsite pools showed a decline trend in about 10 years after logging. Switching from CVL to RIL could increase fluxes in sawnwood $60 \%$ higher than that under CVL, while reducing fluxes in short-lived onsite and offsite wood residues. Not only RIL can increase carbon fluxes in sawnwood, it can also increase production of sawnwood and retain more carbon in standing forests.
\end{abstract}

\section{Keywords}

Carbon Emissions, Conventional Logging, Harvested Wood Products, REDD+

\section{Introduction}

Forests are important for climate change mitigation because forests can play both roles in either carbon sinks 
or sources depending on forest management. Globally, net sink in forests was estimated at 1.1 PgC year $^{-1}$ between 1990 and 2007 [1] or about 12\% of global carbon emissions from fossil burning and cement production in 2010. Despite increase in carbon sink by global forests, continuous loss of tropical forests was responsible for carbon emissions to the atmosphere. Deforestation in tropical forest emitted about 1.0 PgC year $^{-1}$ between 2000 and 2010 [2]. In addition to sequestering atmospheric carbon, harvested wood products (HWPs) can also store carbon for many years depending on how the products are processed and used. Accounting for carbon storage in HWPs has brought more attention because of the need for reporting sources of remissions or removals to the United National Convention on Climate Change (UNFCCC). Stockmann et al. [3] analyzed carbon storage in HWPs in the Northern region of the United States of America and found that forest management in this region alone created carbon storage in HWPs of about $25.5 \mathrm{TgC}$ in 2010 increasing from just $0.3 \mathrm{TgC}$ in 1910. For the whole USA, annual carbon fluxes in HWPs were estimated at 37 TgC year $^{-1}$ [4]. Dymond [5] developed accounting methods (British Columbia Harvested Wood Products version 1) for HWPs in British Columbia, Canada for 1965-2065. Based on his findings, the author argued that default accounting methods developed by Intergovernmental Panel on Climate Change (IPCC) overestimated carbon emissions in North America and suggested that IPCC modified emission factor from its current default of 1.0 to 0.52 . Haripriya [6] estimated carbon storage in various pools of HWPs due to timber harvesting in India for 200 years. Author suggested that increasing wood durability is likely to increase more carbon storage.

Previous studies provide important information about the current state of research on carbon accounting methods for HWPs from wood harvesting in the North America, Europe, and India. These studies agreed that HWPs stored a large amount of carbon in different forms. Although these studies provide useful discussions for further development of accounting methods, their studies used data on the amount of timber harvested annually in their respective regions without considering carbon storage in other wood components created by logging when forests are harvested such as in branches, top logs, belowground (i.e., dead root), and wood wastes due to wood processing at the sawmill when timber (logs) is processed to make sawnwood for end-use products. Considering these components is particularly important for timber harvested in tropical forests, where logging usually create huge amount of wood wastes in forests [7]-[11] and only logs with good quality are transported to the sawmills for processing. Unlike trees in temperate or boreal forests, tropical trees can be used only up to the first main branch and the majority is left in forests to decay. Whiteman et al. [12] estimated industrial roundwood production in Malaysia and Indonesia at about 83 million $\cdot \mathrm{m}^{3}$ in 1996 and projected to increase to $95 \mathrm{million} \cdot \mathrm{m}^{3}$ in 2010 . Given that only about $30 \%$ of this amount was left in the forests (see [13] [14]), carbon storage in HWPs associated with this amount of roundwood production could be huge.

This study is designed to estimate carbon storage (cumulative fluxes) in various wood components due to selective logging in production forest in Southeast Asia. It is structured as follow: 1) estimation of area of production forests, where selective logging is practiced for a project period of hypothetical implementation between 2015 and 2050; 2) timber harvesting through selective logging of 30 years under conventional logging (CVL) and reduced impact logging (RIL). This comparison of selective logging practices is performed to stimulate discussions on management implications for tropical forests because RIL is a promising practice which could be adopted for achieving a "sustainable management of forests" element of the REDD+ scheme of the UNFCCC; 3) carbon fluxes in various wood components are tracked using the First Order Decay function with different half-life time and decay rates; and 4) policy implications for including carbon storage in HPWs in future climate regime are provided.

\section{Study Methods and Materials}

This study obtained total area of production forest from our previous study [15] in Southeast Asia. Using forest functions defined by FAO [16], our study classified forest land uses to production forest, protected forest, and forest plantation. Area change and forest carbon stocks change for each forest classification were predicted up to 2050. In tropics, commercial logging is commonly carried out in production forest, where mature trees (trees with diameter greater than minimum diameter for harvesting) are selectively logged once per cutting cycle. 


\subsection{Wood Components Created by Selective Logging}

This section focusses on estimating timber harvest, logging mortality, wood products, sawnwood, sawnwood wastes, wood wastes, belowground dead root, branches and top logs of harvested trees (Figure 1) in production forest in Southeast Asia under two logging practices, namely CVL and RIL. The former is assumed to be the business-as-usual practice while the latter is assumed to be a practice adopted when financial support under the UN's REDD+ scheme is available. The difference between CVL and RIL is the amount of logging damages, wood wastes caused by logging and wood processing inefficiency (See [14]).

According to Khun and Sasaki [15], harvest wood and logging mortality (the latter due to damages by logging) can be obtained by

$$
\begin{gathered}
H(t)=\frac{f_{M} f_{H}}{1-r} \times \frac{C S_{\text {above }}(t)}{C C \times B E F} \\
L M(t)=\alpha \times H(t)
\end{gathered}
$$

where

$H(t)$ : Harvested wood at time $t\left(\mathrm{MgC} \mathrm{ha}^{-1} \cdot \mathrm{year}^{-1}\right)$

$L M(t)$ : Logging mortality caused by logging $\left(\mathrm{MgC} \mathrm{ha}^{-1} \cdot \mathrm{year}^{-1}\right)$

$C S_{\text {above }}(t)$ is aboveground carbon stocks (MgC) defined in Equation (5) of Khun and Sasaki [15].

Description of other values and parameters are given in Table 1.

Wood products (WP), sawnwood (SW), wood wastes in the forests (WPW), branches and top logs of harvested and damaged trees (BRA) and belowground dead root (BLD) can be derived by

$$
\begin{gathered}
W P(t)=(1-s) \times H(t) \\
S W(t)=(1-a) \times W P(t) \\
W P W(t)=[H(t)-W P(t)]+L M(t) \\
B R A(t)=[H(t)+L M(t)] \times(1-B E F) \\
B L D(t)=[H(t)+L M(t)] \times 0.16
\end{gathered}
$$

where

$s$ : Proportion of wood wastes to harvested logs. These wastes include broken trunks and high stumps. Based on various sources, Sasaki et al. [13] adopted $s=0.3 \%$ or $30 \%$ for CVL and $s=0.1 \%$ or $10 \%$ for RIL. We used same value for this study.

$a$ : Wood processing efficiency at sawmills (i.e. proportion of wood waste at sawmill). We used same values adopted by Sasaki et al. [13] for wood processing inefficiency ( $a=0.5$ for CVL, and $a=0.4$ for RIL).

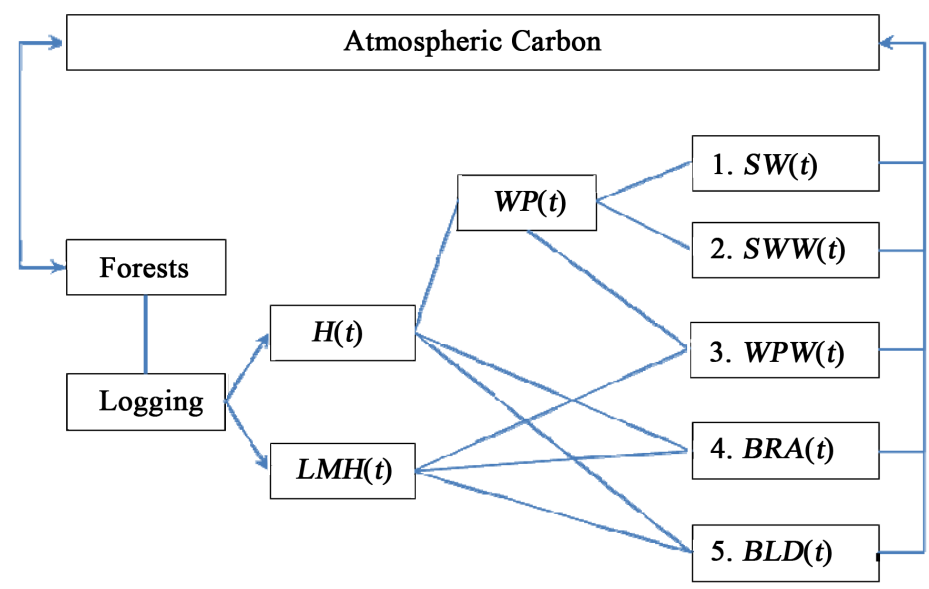

Figure 1. Five wood components created by selective logging. 
Table 1. Initial values and parameters used for production forest (Equations (5)-(7)).

\begin{tabular}{cccc}
\hline Description & $\begin{array}{c}\text { Conventional Logging } \\
(\mathrm{CVL})\end{array}$ & $\begin{array}{c}\text { Reduced Impact Logging } \\
(\mathrm{RIL})\end{array}$ & Remarks \\
\hline Initial Carbon Stocks $C S_{\text {above }}(0)$ & 151.1 & 151.1 & See Khun and Sasaki [15] \\
$f_{M}$ (Fraction of Mature Trees) & 0.43 & 0.43 & See Sasaki et al. [13] \\
$f_{H}$ (Logging Rate) & 0.3 & 0.3 & See Kim Phat et al. [17] \\
$r$ (Illegal Logging Rate) & 0.5 & 0.5 & See Sasaki et al. [13] \\
$C C$ (Cutting Cycle in Year) & 30 & 30 & Common Cutting Cycle \\
$M A I$ (Mean Annual Increment) & 0.76 & 0.76 & See Khun and Sasaki [15] \\
$B E F$ (Biomass Expansion Factor) & 1.74 & 1.74 & Brown [18] \\
$\alpha$ & 0.4 & 0.14 & See Sasaki et al. [13] \\
\hline
\end{tabular}

$B E F$ : Biomass expansion factor. We used 1.74 as reported by Brown [18].

$0.16 \%$ or $16 \%$ is the proportion of root to aboveground biomass [19].

Carbon fluxes in each wood component above at every time step are estimated by first order decay function followed Grier [20]. This method was also recently used by Stockmann et al. [3] to estimate carbon storage in harvested woodproducts from the United States forest service northern region. Carbon remaining in any wood component created by selective logging at any time carbon is obtained by:

$$
C F_{i}(t)=C_{i}(t 0) \times \mathrm{e}^{-k \times t}
$$

where

$C(t 0)$ : Initial amount of carbon at year zero (i.e. starting year of the model)

$t$ : Elapsed time (years)

$k_{i}$ : constant decay rate for wood component $i$, which can be derived by

$$
k_{i}=\frac{\ln (2)}{H L_{i}}
$$

where

$H L_{i}$ : Half-life time (years) of wood component $i . H L$ is the time after which half the carbon is no longer in use. Table 2 provides information on $H L$ for various wood component.

Based on 32 native tree species in Malaysian Borneo, Mori et al. [21] estimated $H L$ time ranging about just about 1 year to as high as 28 years for dead trees, with average of about 4.3 years. Tobin et al. [22] estimated the decay rates of 31 stumps and 51 logs at 0.0592 and 0.0466 or 11.7 and 14.9 years of HL time, respectively. Based on data from 199 dead trees in Amazonian forest, Chambers et al. [23] estimated average decay rate of medium-size trees of $0.17-0.19$ per year or about 4 years of $H L$ time. There are large variations of decay rates ranging from $0.015\left(H L=46.2\right.$ years) to $0.67\left(H L=1.0\right.$ year) year $^{-1}$. Annual temperature in tropical forests is warmer than that in temperate forests, and therefore the decay rate of dead trees in tropical forests is much faster. Given these large variations and for simplicity, we assumed that HL times for SWW, WPW, BRA, and BLD at 3, 5,4 , and 5 years, respectively (Table 2).

\subsection{Cumulative Carbon Fluxes}

Cumulative carbon fluxes in each wood component per hectare are obtained by

$$
C C F_{n}(t n)=C F_{1}(t n)+C F_{2}(t n-1)+\cdots+C F_{n}(t 1)
$$

where

$C F_{n}(t n)$ : carbon fluxes in wood component occurred at harvest time $t=n\left(\mathrm{MgC} \mathrm{ha}^{-1}\right)$

Cumulative carbon fluxes in each wood component due to logging in production forest in Southeast Asia are therefore

$$
T C F(t n)=P D F(t) \times C C F_{n}(t n)
$$


Table 2. Half-life time of five wood components considered in this study.

\begin{tabular}{|c|c|c|c|c|}
\hline Name & Wood Components (i) & $H L$ (years) & Sources & $k$ \\
\hline SW & Sawn wood & 30 & IPCC [24] & 0.0231 \\
\hline SWW & $\begin{array}{l}\text { Wood wastes when logs are } \\
\text { processed to sawn wood at sawmills }\end{array}$ & 3 & Assumntions & 0.2310 \\
\hline WPW & $\begin{array}{l}\text { Wood product wastes due to logging } \\
\text { damages left behind in the forests }\end{array}$ & 5 & $\begin{array}{l}\text { based on Mori et } \\
\text { al. [21], Tobin et }\end{array}$ & 0.1386 \\
\hline BRA & Branches and top logs left behind in the forests & 4 & $\begin{array}{l}\text { al. [22], Chambers } \\
\text { et al. [23] }\end{array}$ & 0.1733 \\
\hline BLD & Belowground dead root & 5 & & 0.1386 \\
\hline
\end{tabular}

where

TCF $(t n)$ : Cumulative carbon fluxes in each wood component (TgC).

$\operatorname{PDF}(t)$ : Area of production forest (million ha) taken from our previous study [15].

\subsection{Converting from Carbon to Wood Volume}

Since existing publications on carbon stock changes affected by logging in Southeast Asia are rare, we need to convert carbon stocks in harvested timber, wood products, and sawn wood to cubic volume so that results of this study can be validated against that in previous studies. We converted harvested timber, wood products, and sawn wood from carbon to cubic meter of wood using the following equation:

$$
W_{i}(t)=\frac{C W_{i}(t)}{W D \times C T}
$$

where

$W_{i}(t)$ : Amount of wood in wood component $i$ (harvested wood, wood products or sawnwood) at time $t$ $\left(\mathrm{m}^{3} \cdot \mathrm{ha}^{-1}\right)$.

$C W_{i}(t)$ : Amount of carbon in wood component $i\left(\mathrm{MgC} \mathrm{ha}^{-1}\right)$.

WD : Wood density $\left(\mathrm{Mg} \mathrm{m}^{-3}\right)$. WD is 0.56 [18].

$C T$ : Carbon content in dry wood ( $\left.\mathrm{MgC} \mathrm{Mg}^{-1}\right)$. CT is 0.5 [24].

Total production for each wood component is therefore

$$
T W_{i}=P d F(t) \times W_{i}(t)
$$

where

$T W_{i}(t)$ : Total production of wood component $i\left(\right.$ million $\left.\cdot \mathrm{m}^{3}\right)$.

\section{Results and Discussions}

\subsection{Wood Products and Other Wood Components Created by Selective Logging}

Wood products are important sources for housing and economic development in Southeast Asia. Between 2015 and 2050 of the modeling timeframe, logging produced about ( \pm for standard error) $0.83( \pm 0.01) \mathrm{m}^{3} \cdot$ ha $^{-1}$, declining about $-0.57 \%$ year $^{-1}$. This decline was due to overexploitation and logging damages (harvested wood and logging damages are greater than mean annual increment). Other studies have found that selective logging in the tropics resulted in significant decrease of stand volume or carbon stocks [25]-[28].

Wood products (roundwood) from logging in production forest in Southeast Asia were 146.6 ( \pm 5.4$)$ million* $\mathrm{m}^{3} \cdot$ year $^{-1}$ between 2015 and 2050. Overexploitation coupled with decline in area of production forests [15] caused a decrease of roundwood production of about 2.2 million $\cdot \mathrm{m}^{3}$ annually over the same period (Figure 2 ). Of the 146.6 million $\cdot \mathrm{m}^{3}$, about $73.3( \pm 2.7)$ million $\cdot \mathrm{m}^{3}$ were processed further to sawnwood. The remainder (50\%) were wood wastes at the processing sawmills. Other wood components created by selective logging include $217.0( \pm 8.0), 46.5( \pm 1.7)$, and $62.8( \pm 2.3)$ million $\cdot \mathrm{m}^{3} \cdot \mathrm{year}^{-1}$ of branches and top logs, belowground dead root, and wood wastes due to felling, trimming and transporting to sawmills, respectively (Table 3). Wood components (except sawnwood) are usually excluded in any reports by any government and so are carbon fluxes in 


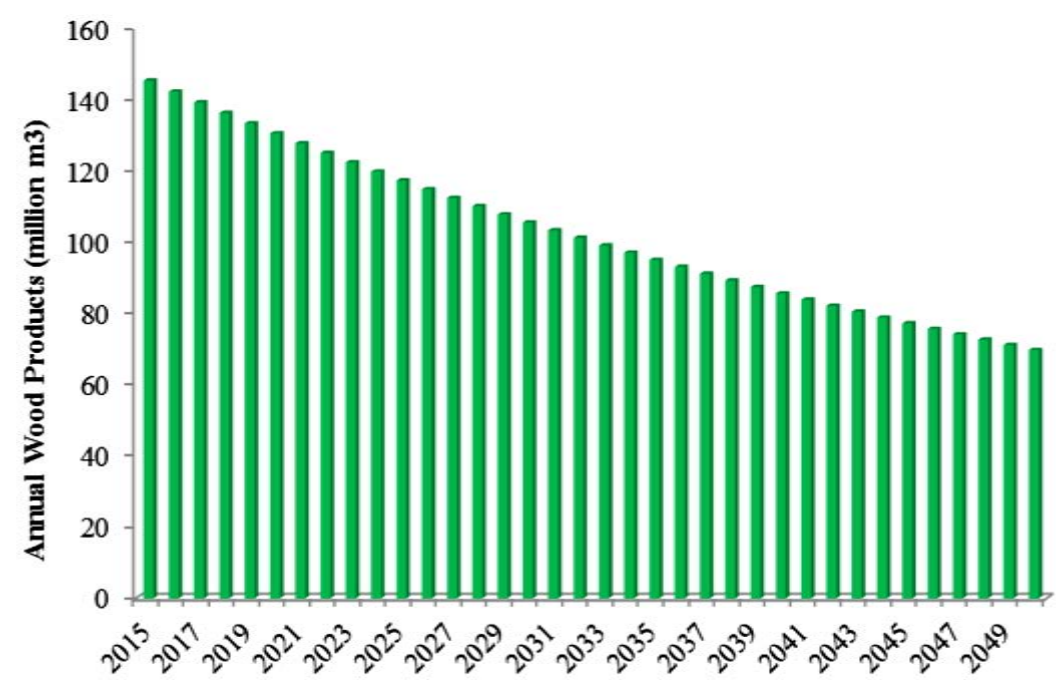

Figure 2. Annual wood products (round wood) in Southeast Asia (2015-2050).

Table 3. Mean annual production of various wood components created by selective logging (2015-2059).

\begin{tabular}{ccccc}
\hline Wood Component $(i)$ & Mean $\left(\right.$ million $\left.\cdot \mathrm{m}^{3}\right)$ & Standard Error & Percentage to Total & Classification \\
\hline SW & 73.3 & 2.7 & $15.5 \%$ & SW \\
SWW & 73.3 & 2.7 & $15.5 \%$ & Offsite \\
BRA & 217.0 & 8.0 & $45.9 \%$ & Onsite \\
BLD & 46.5 & 1.7 & $9.8 \%$ & Onsite \\
WPW & 62.8 & 2.3 & $13.3 \%$ & Onsite \\
Total & 473.1 & & $100.0 \%$ & \\
\hline
\end{tabular}

these wood components.

Waggener and Lane [29] reported industrial roundwood production in Southeast Asia about $68.1 \mathrm{million} \cdot \mathrm{m}^{3}$ in 1980 and increased to 87.1 million $\mathrm{m}^{3}$ in 1992. Using these data (Figure 3) and based on linear projection, average roundwood production between 2015 and 2050 was $134.4( \pm 2.3)$ million· $\mathrm{m}^{3}$, only about 8\% lower than our estimate. This lower prediction may be due to the fact that data of Waggener and Lane [29] did not include wood production from illegal logging. If $50 \%$ of illegal logging was included, wood production using data from Waggener and Lane [29] went up to 268.8 million $\cdot \mathrm{m}^{3}$. This higher value would be possible given that their data were collected when Southeast Asia still had higher forest cover and countries such as Philippines and Thailand were the among major producers of roundwood [30]. Since 1990s, forest resources in the Philippines and Thailand became exhausted. In addition, forest cover in Cambodia, Myanmar, Indonesia, and Laos has declined sharply over the last 15 years [16]. As forest resources in many countries in Southeast Asia continue to decline, it is expected that roundwood product from natural forests (i.e. production forest in our study) will continue to decline. Based on data published by [30], roundwood production in Southeast Asia peaked at about 105 million $\cdot \mathrm{m}^{3}$ in 1993 but decline to about 80 million $\cdot \mathrm{m}^{3}$ in 2007 . Whiteman et al. [12] projected the production of industrial roundwood in Malaysia and Indonesia alone to $95.2 \mathrm{million} \cdot \mathrm{m}^{3}$ in 2010 . Our findings of roundwood production are well within the range of previous studies.

\subsection{Carbon Fluxes in Wood Products and Other Wood Components}

Annual fluxes in sawnwood product declined from $0.26 \mathrm{MgC}$ in 2015 to $0.21 \mathrm{MgC} \mathrm{ha}^{-1}$ in 2015 with annual decline rate of about $0.57 \%$. Average fluxes were $0.23( \pm 0) \mathrm{MgC} \mathrm{ha}^{-1}$ over the same period. Cumulative carbon fluxes in sawnwood were just $0.26 \mathrm{MgC} \mathrm{ha}^{-1}$ in 2015 but cumulatively increased to $5.68 \mathrm{MgC} \mathrm{ha}^{-1}$ in 2050 with increase rate of about 59.2\% annually between 2015 and 2050 (Figure 4). 


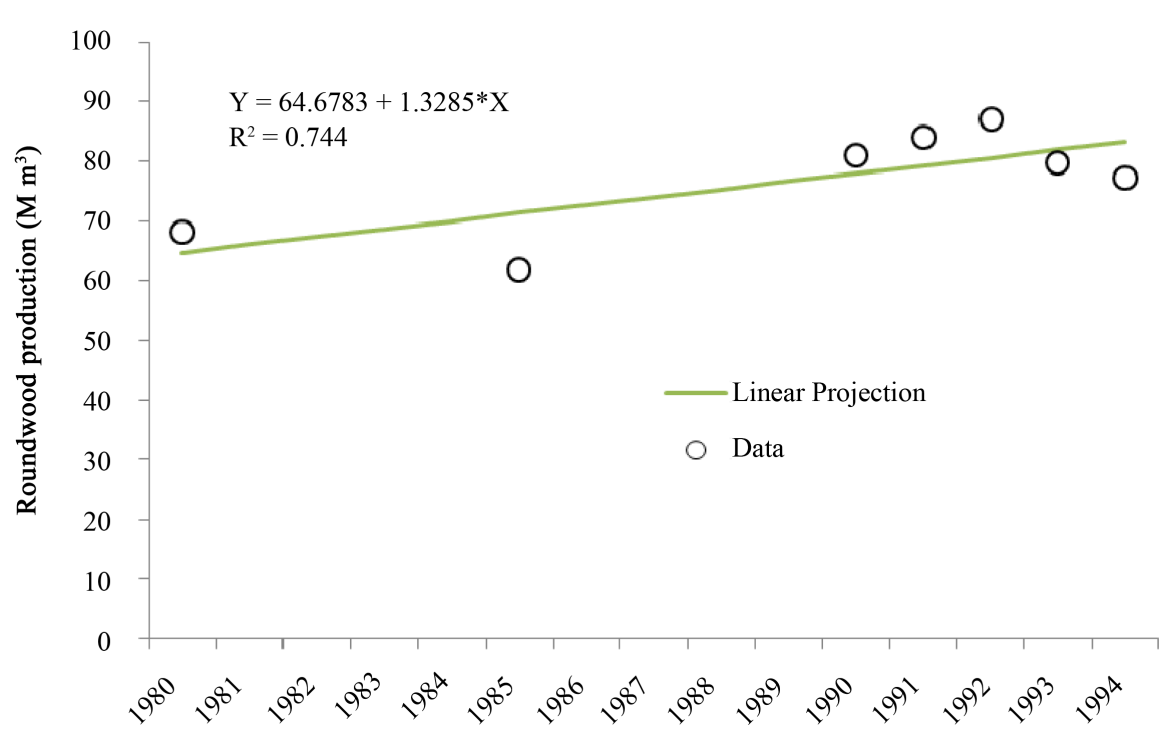

Figure 3. Industrial roundwood production reported by Waggener and Lane and linear fitting curve used to project future production. Source: Waggener and Lane [29].

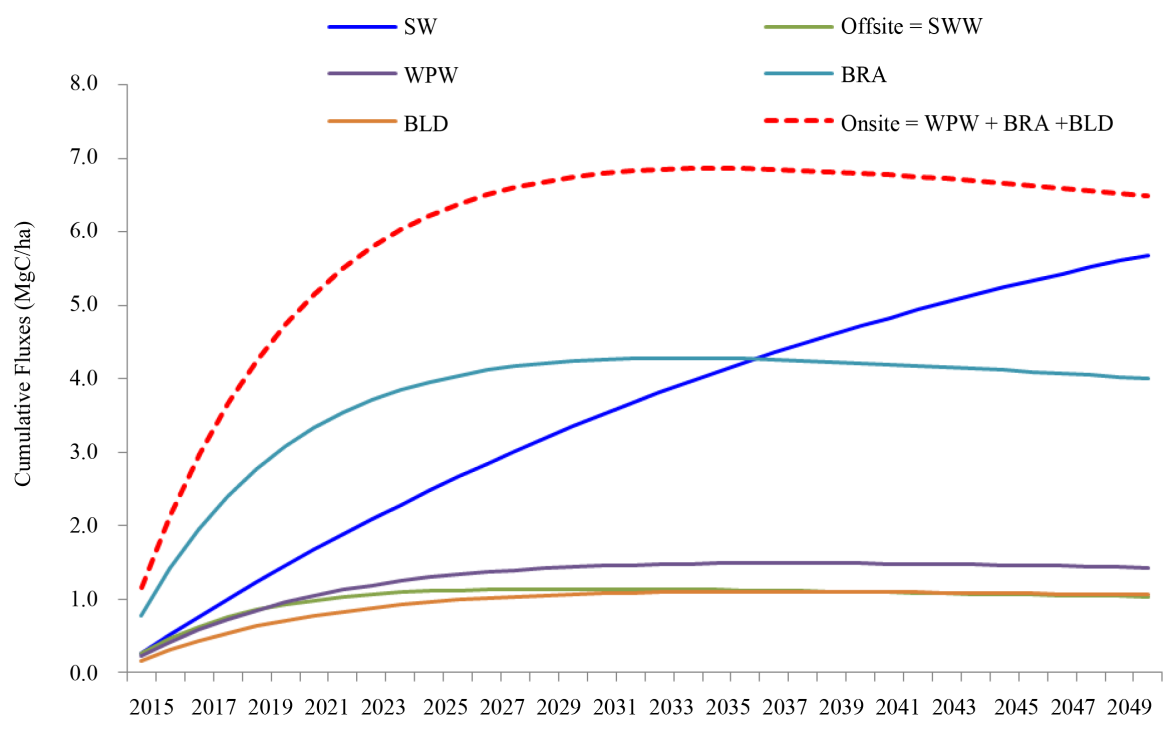

Figure 4. Cumulative carbon fluxes in various wood components created by logging.

Cumulative carbon fluxes in wood wastes at sawmill (SWW) were $0.26 \mathrm{MgC}$ in 2015 and $1.04 \mathrm{MgC}$ in 2050 after reaching the highest point at $1.14 \mathrm{MgC}$ in 2030. Similar patterns of cumulative fluxes were also seen in wood wastes in the forests (WPW), branches and top logs (BRA), and belowground dead root (BLD). Cumulative carbon fluxes were $0.22,0.77$, and $0.17 \mathrm{MgC} \mathrm{ha}^{-1}$ in 2015 and 1.43, 4.01, and $1.06 \mathrm{MgC} \mathrm{ha}^{-1}$ in 2050 for WPW, BRA, and BLD, respectively (Figure 4). Cumulative carbon fluxes began to decline quickly and emit carbon in about 10 years after harvesting.

Our models suggested that selective logging created huge amount of wood residues remained in the forests and at sawmills. Feldpausch et al. [31] found that logging produced more wood residues in the selectively logged forests. Onsite residues that include branches and top logs, wood waste due to logging (broken logs, stumps), and belowground dead root account for high cumulative carbon fluxes but these fluxes began to decline when inflow fluxes are smaller than outflow fluxes due to wood decay. Offsite fluxes in wood waste at the sawmills has same pattern to that of onsite fluxes. Fluxes in sawnwood continue to increase depending on how sawnwood is further utilized to further make furniture or houses or other building infrastructures. 


\subsection{Cumulative Carbon Fluxes Due to Selective Logging in Southeast Asia}

Cumulative carbon fluxes in sawnwood, onsite and offsite wood components created by selective logging under CVL in production forest in Southeast Asia were estimated at 378.7, 433.0, and 69.1 TgC in 2050 increasing from 29.1, 129.4, and 29.1 TgC in 2015, respectively. Cumulative fluxes in onsite and offsite wood components declined sharply after reaching the highest level at 2028 (13 years after logging) and 2025, respectively (Figure 5). In contrast and despite decline in area of production forests [15], cumulative fluxes in sawnwoon still increased and reached the highest level at $378.8 \mathrm{TgC}$ in 2049. These fluxes began to decline gradually thereafter due to the decline in area of production forest in Southeast Asia [15]. Totally, selective logging under CVL in Southeast Asia resulted in cumulative carbon fluxes of 187.5 TgC in 2015 and 880.8 TgC in 2050. Depending on carbon accounting methods, the increase in cumulative carbon fluxes could be used to offset carbon emissions from tropical deforestation.

\subsection{Impacts of Forest Management on Carbon Fluxes}

Reduced impact logging (RIL) is assumed as a logging practice that will be adopted for "sustainable management of forests" element of the REDD+ scheme. As RIL was able to significantly reduce wood wastes in the forests (WPW), wood wastes at sawmills (SWS), and logging damages, carbon fluxes in short-lived wood components can be reduced and therefore reduce emissions when inflow fluxes are smaller than outflow fluxes. By being able to reduce damages, more sawnwood production can be achieved from the same amount of harvested timber. Because sawnwood has longer half-life time carbon, more carbon storage can be achieved as shown in Figure 6. Cumulative fluxes in sawnwood under RIL and CVL increased to 608.4 and 378.7 TgC in 2050 from 44.8 and 29.1 TgC in 2015, respectively. After 35 years, cumulative fluxes under RIL were 229.7 TgC higher than that in CVL. In addition, RIL was able to reduce fluxes in short-lived wood components at 100.6 TgC (Figure 6, Table 4). Not only RIL could retain more carbon in standing forests [13], but it can also increase sawnwood product and carbon fluxes in sawnwood.

Our study findings suggest that adopting RIL not only lead to more carbon being retained in forests but also increase wood production and carbon storage in long-lived wood product. In addition, long-lived wood products could be achieved by technology transfer. If half-life time in sawnwood can be lengthened, more carbon storage in harvested wood products can be further achieved.

\subsection{Sensitivity Analysis}

There are several potential sources of uncertainty in this study. Initial carbon stocks in tropical forests vary

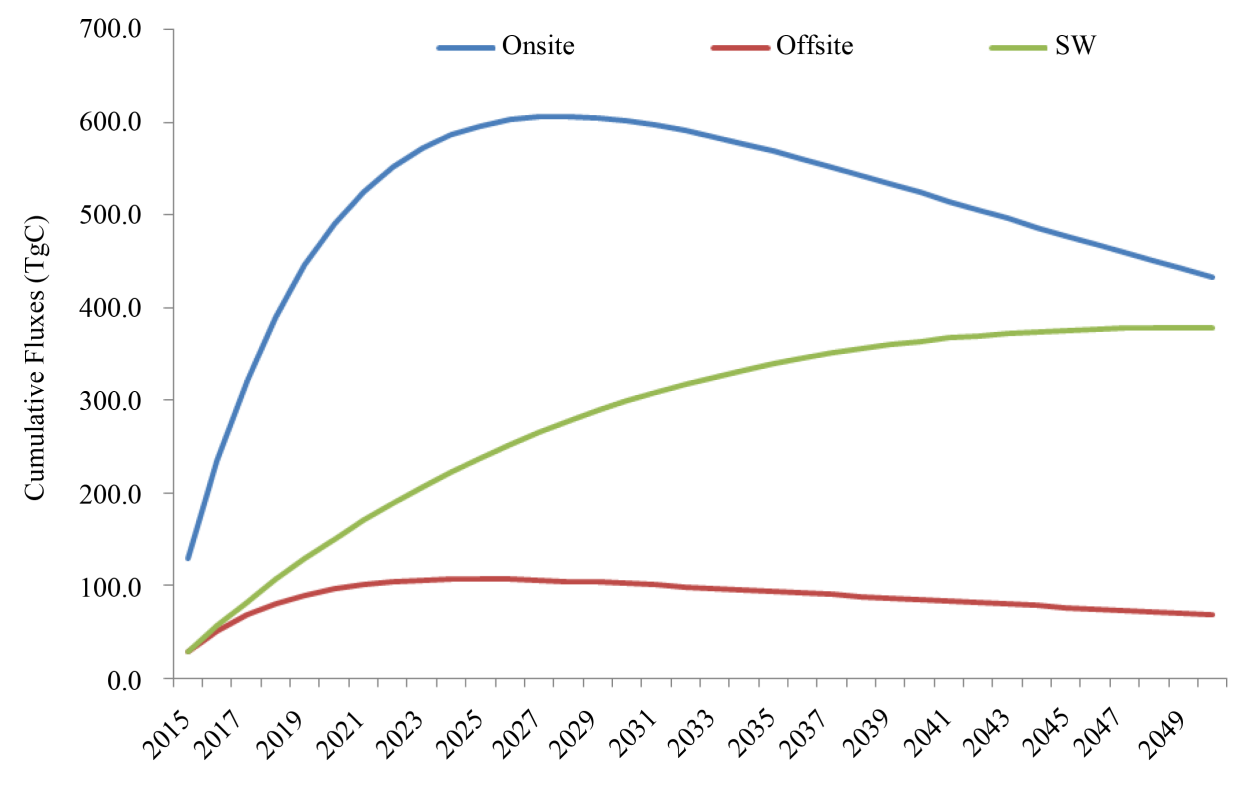

Figure 5. Cumulative carbon fluxes in onsite, offsite, and sawnwood products. 


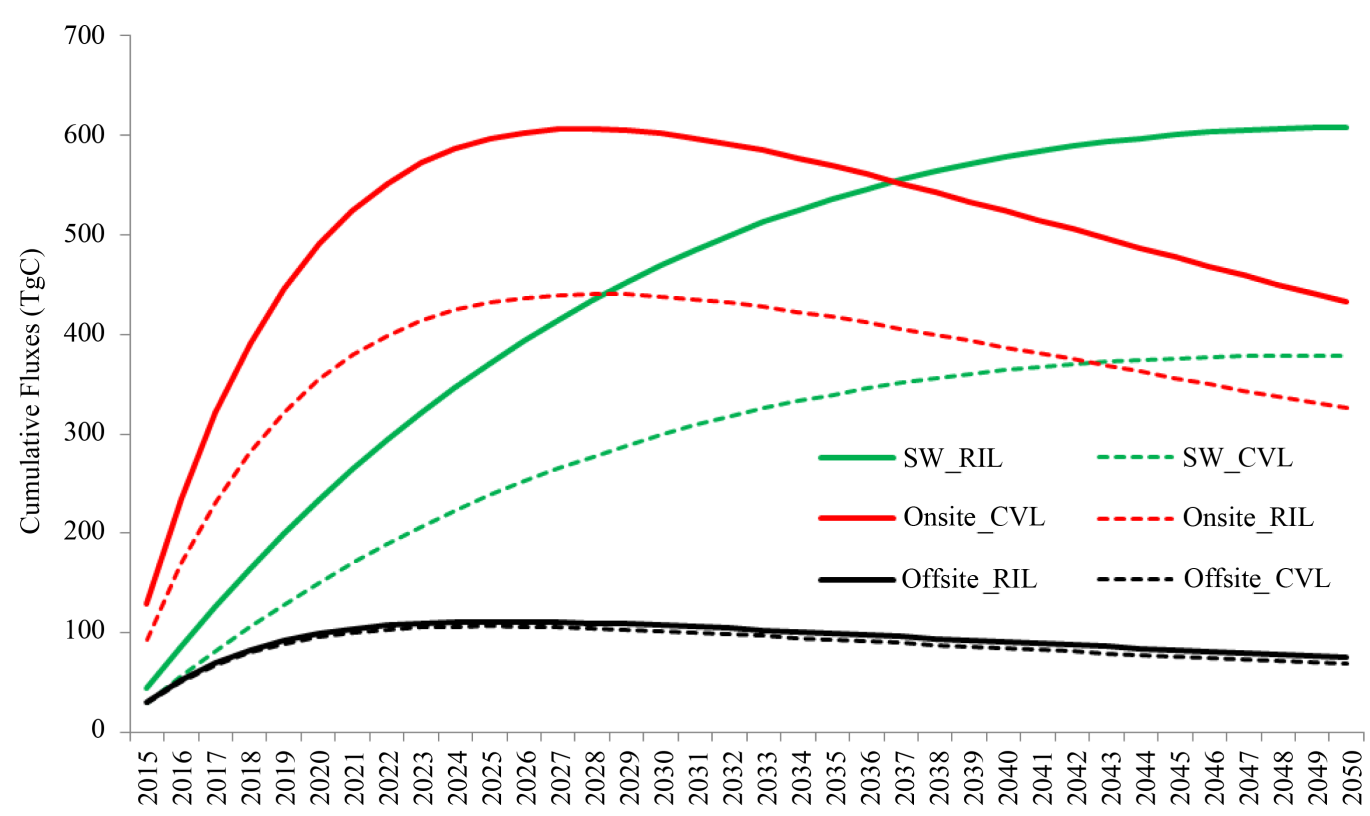

Figure 6. Cumulative carbon fluxes due to selectively logging under RIL and CVL in production forest in Southeast Asia.

Table 4. Summary of cumulative carbon fluxes due to selectively logging under RIL and CVL in production forest in Southeast Asia.

\begin{tabular}{|c|c|c|c|c|c|c|c|c|}
\hline \multirow{2}{*}{ Year } & \multicolumn{4}{|c|}{ Reduced Impact Logging (RIL) (TgC) } & \multicolumn{4}{|c|}{ Conventional Logging (CVL) (TgC) } \\
\hline & Onsite & Offsite & SW & Total & Onsite & Offsite & SW & Total \\
\hline 2015 & 93.4 & 29.9 & 44.8 & 168.1 & 129.4 & 29.1 & 29.1 & 187.5 \\
\hline 2025 & 432.2 & 111.6 & 371.5 & 915.2 & 596.8 & 106.8 & 238.0 & 941.7 \\
\hline 2035 & 417.5 & 99.6 & 536.1 & 1053.2 & 569.4 & 93.6 & 339.6 & 1002.6 \\
\hline 2045 & 356.1 & 83.1 & 600.6 & 1039.8 & 477.7 & 76.5 & 376.0 & 930.2 \\
\hline 2050 & 325.7 & 75.7 & 608.4 & 1009.9 & 433.0 & 69.1 & 378.7 & 880.8 \\
\hline \multicolumn{9}{|c|}{ Differences of Cumulative Fluxes under RIL vs CVL } \\
\hline \multirow{2}{*}{ Year } & \multicolumn{2}{|c|}{ Onsite } & \multicolumn{2}{|c|}{ Offsite } & \multicolumn{2}{|c|}{ SW } & \multicolumn{2}{|c|}{ Total } \\
\hline & $(\operatorname{TgC})$ & $(\%)$ & $(\operatorname{TgC})$ & $(\%)$ & $(\operatorname{TgC})$ & $(\%)$ & $(\operatorname{TgC})$ & (\%) \\
\hline 2015 & -36.0 & -27.8 & 0.8 & 2.9 & 15.8 & 54.3 & -19.4 & -10.3 \\
\hline 2025 & -164.6 & -27.6 & 4.8 & 4.5 & 133.4 & 56.0 & -26.4 & -2.8 \\
\hline 2035 & -151.9 & -26.7 & 6.1 & 6.5 & 196.5 & 57.9 & 50.7 & 5.1 \\
\hline 2045 & -121.5 & -25.4 & 6.6 & 8.6 & 224.6 & 59.7 & 109.6 & 11.8 \\
\hline 2050 & -107.3 & -24.8 & 6.6 & 9.6 & 229.7 & 60.7 & 129.1 & 14.7 \\
\hline
\end{tabular}

greatly depending on many factors such as forest types, locations, and levels of disturbance. These variations could result in up to $60 \%$ biases of carbon estimates in tropical forests [32]-[34]. For instance, FAO [16] estimated average carbon stocks in tropical Asia at $93 \mathrm{MgC} \mathrm{ha}^{-1}$, while Friedlingstein et al. [35] (2010) and Baccini et al. [2] estimated at 160 and $115 \mathrm{MgC} \mathrm{ha}^{-1}$, respectively. Another potential source of uncertainty is the use of illegal logging ( $50 \%$ of all harvested wood). Illegal logging usually is not reported in any official data of wood production in tropical countries. This is due probably to the lack of proper investigation or the difficulty in con- 
trolling illegal logging over large area of tropical forests. Using 166, 115, and $93 \mathrm{MgC} \mathrm{ha}^{-1}$ as initial value for our study, wood products in Southeast Asia were 154.6, 114.3, and 94.7 million $\cdot \mathrm{m}^{3} \cdot \mathrm{year}^{-1}$, respectively between 2015 and 2050 for 50\% ( $(r=0.5)$ rate of illegal logging was used. Using same initial carbon stocks but different rates of illegal logging, wood products changed significantly over the same period (Table 5).

There are other factors that could affect results of our study. Not all tropical production forests are suitable for logging due to the presence of water surface, villagers, and environmentally and socially sensitive areas (such as steep slopes, bufferzones around villagers, heritage sites, and so on). These areas are commonly referred to inoperable area, an area where logging can not be carried out. By logging regulation, logging on environmentally and socially sensitive areas is strictly prohibited.

\section{Conclusions}

Selective logging in tropical forests produces wood production for construction materials necessary to support economic development. Million cubic meters of wood were harvested from the forest every year in Southeast Asia, but carbon fluxes in various harvested wood were rarely included in previous studies. We used first order decay function to estimate carbon fluxes in various wood components created by selective logging in production forest in Southeast Asia under CVL and RIL. Apart from producing about $73.3( \pm 2.7) \mathrm{millon} \cdot \mathrm{m}^{3}$ of sawnwood, selective logging resulted in cumulative carbon fluxes of 3.5 - 5.5, 1.0 - 1.1, $0.4-1.3,3.2-3.8$, and $0.8-0.9$ $\mathrm{MgC} \mathrm{ha}{ }^{-1}$ in SW, SWW, WPW, BRA, and BLD, respectively after 35 years of logging depending on logging practices (CVL or RIL). Due to fast decay rates, carbon fluxes in SWW, WPW, BRA, and BLD began to emit carbon in about 10 years after harvesting while fluxes in sawnwood continued to increase despite decrease in area of production forest. By classifying WPW, BRA, and BLD in onsite fluxes and SWW in offsite carbon fluxes, we could estimate total fluxes due to selective logging in production forest in Southeast Asia. Total fluxes under CVL were 129.4, 29.1, and 29.1 TgC at time of logging and 433.0, 69.1, and 378.7 TgC in onsite, offsite, and sawnwood, respectively after 35 years of logging. Our study suggests that switching from conventional logging to reduced impact logging could further increase carbon fluxes in sawnwood to $608.4 \mathrm{TgC}$ after 35 years of logging while reducing short-lived onsite and offsite wood residues.

This study indicates that selective logging can create huge carbon fluxes in various wood components. Depending on carbon accounting methods, these fluxes could be used to offset carbon emissions from deforestation and forest degradation. Including carbon fluxes (credits) in sawnwood in climate change mitigation options would provide incentives for better utilization of harvested wood products and management of tropical forests. Otherwise, destructive logging and careless use of harvested wood will continue unabated. Providing incentives for carbon offset in harvested wood products will also stimulate the development of wood processing technology, which will eventually result in more sawnwood production and more carbon storage in harvested wood products, while retaining more carbon in standing forests.

There are some limitations to our study. Initial carbon stocks and illegal logging strongly affect the amount of timber to be harvested and other wood components. More forest inventory data are important for determining initial carbon stocks in the forests. Rate of illegal logging is difficult to determine because of the large area of tropical forests and this rate is affected by many factors such as political stability and demand for timber production. It is recommended revisions to initial carbon stocks and rate of illegal logging be revised in future study when more data become available.

Table 5. Average annual wood products under different initial carbon stocks and rates of illegal logging (2015-2050).

\begin{tabular}{cllll}
\hline & \multicolumn{4}{c}{ Annual wood products based on three rate of illegal logging $\left(\mathrm{million}^{3} \cdot \mathrm{m}^{3} \cdot \mathrm{year}^{-1}\right)$} \\
\cline { 2 - 5 } Initial carbon stocks $\left(\mathrm{MgC} \mathrm{ha}^{-1}\right)$ & $\mathrm{r}=0.5(50 \%)$ & $\mathrm{r}=0.3(30 \%)$ & $\mathrm{r}=0.1(10 \%)$ & $\mathrm{r}=0.1(0 \%)$ \\
\hline 151.1 (This study) & 146.6 & 110.1 & 88.1 & 80.1 \\
$160.0[35]$ & 154.6 & 116.1 & 92.9 & 84.4 \\
$115.0[2]$ & 114.3 & 85.8 & 68.7 & 62.4 \\
$93.0[16]$ & 94.7 & 71.0 & 56.8 & 51.6 \\
\hline
\end{tabular}




\section{Acknowledgements}

This study was supported by a Grant-in-Aid for Scientific Research Category A (No. 24252002) from the Ministry of Education, Culture, Sports, Science and Technology of Japan.

\section{Conflict of Interest Statement}

The authors declare no conflict of interest.

\section{References}

[1] Pan, Y., Birdsey, R.A., Fang, J., Houghton, R., et al. (2011) A Large and Persistent Carbon Sink in the World’s Forests. Science, 333, 988-993. http://dx.doi.org/10.1126/science.1201609

[2] Baccini, A., Goetz, S.J., Walker, W.S., Laporte, N.T., Sun, M., Sulla-Menashe, D., Hackler, J., Beck, P.S.A., Dubayah, R., Friedl, M.A., Samanta, S. and Houghton, R.A. (2012) Estimated Carbon Dioxide Emissions from Tropical Deforestation Improved by Carbon-Density Maps. Nature Climate Change, 2, 182-186. http://dx.doi.org/10.1038/nclimate1354

[3] Stockmann, K., Anderson, N., Skog, K., Healey, S., Loeffler, D., Jones, G. and Morrison, J. (2012) Estimates of Carbon Stored in Harvested Wood Products from the United States Forest Service Northern Region, 1906-2010. Carbon Balance and Management, 7, 1-16. http://dx.doi.org/10.1186/1750-0680-7-1

[4] Heath, L.S., Birdsey, R.A., Row, C. and Plantinga, A.J. (1996) Carbon Pools and Flux in US Forest Products. In: Apps, M.J. and Price, D.T., Eds., Forest Ecosystems, Forest Management, and the Global Carbon Cycle, NATO ASI Series I: Global Environmental Changes, Vol. 40, Springer, Berlin, 271-278.

[5] Dymond, C. (2012) Forest Carbon in North America: Annual Storage and Emissions from British Columbia's Harvest, 1965-2065. Carbon Balance and Management, 7. http://dx.doi.org/10.1186/1750-0680-7-8

[6] Haripriya, G.S. (2002) A Framework for Assessing Carbon Flow in Indian Wood Products. Environment, Development and Sustainability, 3, 229-251.

[7] Sist, P. and Ferreira, F.N. (2007) Sustainability of Reduced-Impact Logging in Eastern Amazonia. Forest Ecology and Management, 243, 199-209. http://dx.doi.org/10.1016/j.foreco.2007.02.014

[8] Putz, F.E., Zuidema, P.A., Pinard, M.A., Boot, R.G.A., Sayer, J.A., Sheil, D., Sist, P. and Vanclay, J.K. (2008) Improved Tropical Forest Management for Carbon Retention. PLoS Biology, 6, e166. http://dx.doi.org/10.1371/journal.pbio.0060166

[9] Putz, F.E., Zuidema, P.A., Synnott, T., Peña-Claros, M., Pinard, M.A., Sheil, D., Vanclay, J.K., Sist, P., Gourlet-Fleury, S., Griscom, B., Palmer, J. and Zagt, R. (2012) Sustaining Conservation Values in Selectively Logged Tropical Forests: The Attained and the Attainable. Conservation Letters. http://dx.doi.org/10.1111/j.1755-263X.2012.00242.x

[10] Souza Jr., C.M. and Roberts, D. (2005) Mapping Forest Degradation in the Amazon Region with Ikonos Images. International Journal of Remote Sensing, 26, 425-429. http://dx.doi.org/10.1080/0143116031000101620

[11] Asner, G.P., Broadbent, E.N., Oliveira, P.J.C., Keller, M., Knapp, D.E. and Silva, J.N. (2006) Condition and Fate of Logged Forests in the Brazilian Amazon. Proceedings of the National Academy of Sciences, 103, 12947-12950. http://dx.doi.org/10.1073/pnas.0604093103

[12] Whiteman, A., Brown, C. and Bull, G. (1999) Forest Product Market Developments: The Outlook for Forest Product Markets to 2010 and the Implications for Improving Management of the Global Forest Estate. Working Paper: FAO/FPIRS/02 Prepared for the World Bank Forest Policy Implementation Review and Strategy. FAO, Rome, 141 p.

[13] Sasaki, N., Kimsun, C. and Ty, S. (2012) Managing Production Forests for Timber Production and Carbon Emission Reductions under the REDD+ Scheme. Environmental Science \& Policy, 23, 35-44. http://dx.doi.org/10.1016/j.envsci.2012.06.009

[14] Sasaki, N. and Putz, F.E. (2009) Critical Need for New Definitions of Forest and Forest Degradation in Global Climate Change Agreements. Conservation Letters, 2, 226-232. http://dx.doi.org/10.1111/j.1755-263X.2009.00067.x

[15] Khun, V. and Sasaki, N. (2014) Re-Assessment of Forest Carbon Balance in Southeast Asia: Policy Implications for REDD+. Low Carbon Economy, 5, 153-171. http://dx.doi.org/10.4236/lce.2014.54016

[16] Food and Agriculture Organization of the United Nations (2010) Global Forest Resources Assessment 2010. FAO Forestry Paper 163, FAO, Rome.

[17] Kim Phat, N., Knorr, W. and Kim, S. (2004) Appropriate Measures for Conservation of Terrestrial Carbon StocksAnalysis of Trends of Forest Management in Southeast Asia. Forest Ecology Management, 191, 283-299. http://dx.doi.org/10.1016/j.foreco.2003.12.019

[18] Brown, S. (1997) Estimating Biomass and Biomass Change of Tropical Forests: A Primer. FAO Forestry Paper 134, 
FAO, Rome.

[19] Aye, Y., Pampasit, S., Umponstira, C., Thanacharoenchanaphas, K. and Sasaki, N. (2014) Estimation of Carbon Emission Reductions by Managing Dry Mixed Deciduous Forest: Case Study in Popa Mountain Park. Low Carbon Economy, 5, 80-93. http://dx.doi.org/10.4236/lce.2014.52009

[20] Grier, C.C. (1978) A Tsuga heterophylla-Picea sitchensis Ecosystem of Coastal Oregon: Decomposition and Nutrient Balance of Fallen Logs. Canadian Journal of Forest Research, 8, 198-206. http://dx.doi.org/10.1139/x78-031

[21] Mori, S., Itoh, A., Nanami, S., Tan, S., Chong, L. and Yamakura, T. (2014) Effect of Wood Density and Water Permeability on Wood Decomposition Rates of 32 Bornean Rainforest Trees. Journal of Plant Ecology, 7, 356-363. http://dx.doi.org/10.1093/jpe/rtt041

[22] Tobin, B., Black, K., McGurdy, L. and Nieuwenhuis, M. (2007) Estimates of Decay Rates of Components of Coarse Woody Debris in Thinned Sitka Spruce Forests. Forestry, 80, 455-469. http://dx.doi.org/10.1093/forestry/cpm024

[23] Chambers, J.Q., Higuchi, N., Schimel, J.P., Ferreira, L.V. and Melack, J.M. (2000) Decomposition and Carbon Cycling of Dead Trees in Tropical Forests of the Central Amazon. Oecologia, 122, 380-388. http://dx.doi.org/10.1007/s004420050044

[24] IPCC (2006) IPCC Guidelines for National Greenhouse Gas Inventories. In: Eggleston, H.S., Buendia, L., Miwa, K., Ngara, T. and Tanabe, K., Eds., The National Greenhouse Gas Inventories Programme, Institute for Global Environmental Strategies, IGES, Yokohama.

[25] Asner, G.P., Knapp, D.E., Broadbent, E.N., Oliveira, P.J.C., Keller, M. and Silva, J.N.M. (2005) Selective Logging in the Brazilian Amazon. Science, 310, 480-482. http://dx.doi.org/10.1126/science.1118051

[26] Blanc, L., Echard, M., Herault, B., Bonal, D., Marcon, E., Chave, J. and Baraloto, C. (2009) Dynamics of AboveGround Carbon Stocks in a Selectively Logged Tropical Forest. Ecological Applications, 19, 1397-1404. http://dx.doi.org/10.1890/08-1572.1

[27] Mazzei, L., Sist, P., Ruschel, A., Putz, F.E., Marco, P., Pena, W. and Ferreira, J.E.R. (2010) Above-Ground Biomass Dynamics after Reduced-Impact Logging in the Eastern Amazon. Forest Ecology and Management, 259, 367-373. http://dx.doi.org/10.1016/j.foreco.2009.10.031

[28] Zimmerman, B.L. and Kormos, C.F. (2012) Prospects for Sustainable Logging in Tropical Forests. Bioscience, 62, 479-487. http://dx.doi.org/10.1525/bio.2012.62.5.9

[29] Waggener and Lane (1997) Pacific Rim Demand and Supply Situation, Trends and Prospects: Implications for Forest Products Trade in the Asia-Pacific Region. (Asia-Pacific Forestry Sector Outlook Study-Working Paper Series) APFSOS/WP/02, FAO, Rome.

[30] FAO (2011) Southeast Asian Forests and Forestry to 2020. Subregional Report of the Second Asia-Pacific Forestry Sector Outlook Study, FAO’s RAP PUBLICATION 2010/20, Bangkok, 78 p.

[31] Feldpausch, T.R., Jirka, S., Passos, C.A.M., Jasper, F. and Riha, S.J. (2005) When Big Trees Fall: Damage and Carbon Export by Reduced Impact Logging in Southern Amazonia. Forest Ecology and Management, 219, 199-215. http://dx.doi.org/10.1016/j.foreco.2005.09.003

[32] Achard, F., Eva, H.D., Stibig, H.J., et al. (2002) Determination of Deforestation Rates of the World's Humid Tropical Forests. Science, 297, 999-1002. http://dx.doi.org/10.1126/science.1070656

[33] Fearnside, P.M. and Laurance, W.F. (2003) Comment on “Determination of Deforestation Rates of the World's Humid Tropical Forests”. Science, 299, 1015a. http://dx.doi.org/10.1126/science.1078714

[34] Pelletier, J., Kirby, K.R. and Potvin, C. (2012) Significance of Carbon Stock Uncertainties on Emission Reductions from Deforestation and Forest Degradation in Developing Countries. Forest Policy and Economics, 24, 3-11. http://dx.doi.org/10.1016/j.forpol.2010.05.005

[35] Friedlingstein, P., Houghton, R.A., Marland, G., Hackler, J., Boden, T.A., Conway, T.J., et al. (2010) Update on $\mathrm{CO}_{2}$ Emissions. Nature Geoscience, 3, 811-812. http://dx.doi.org/10.1038/ngeo1022 
Scientific Research Publishing (SCIRP) is one of the largest Open Access journal publishers. It is currently publishing more than 200 open access, online, peer-reviewed journals covering a wide range of academic disciplines. SCIRP serves the worldwide academic communities and contributes to the progress and application of science with its publication.

Other selected journals from SCIRP are listed as below. Submit your manuscript to us via either submit@scirp.org or Online Submission Portal.
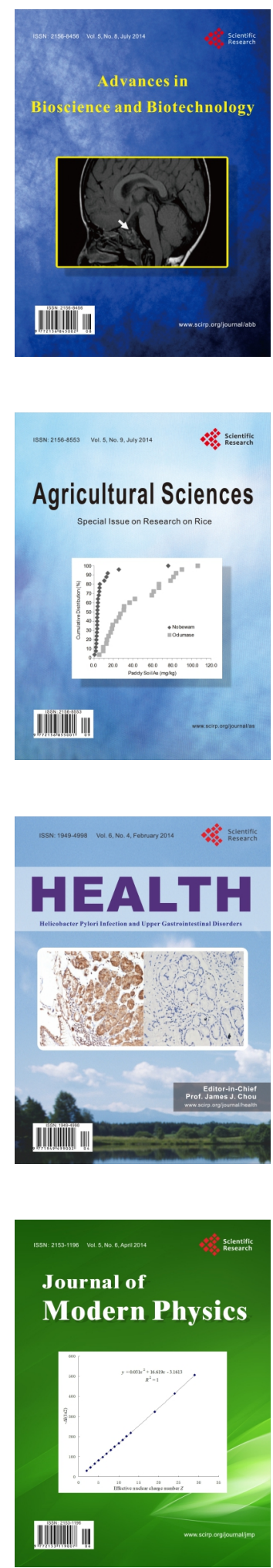
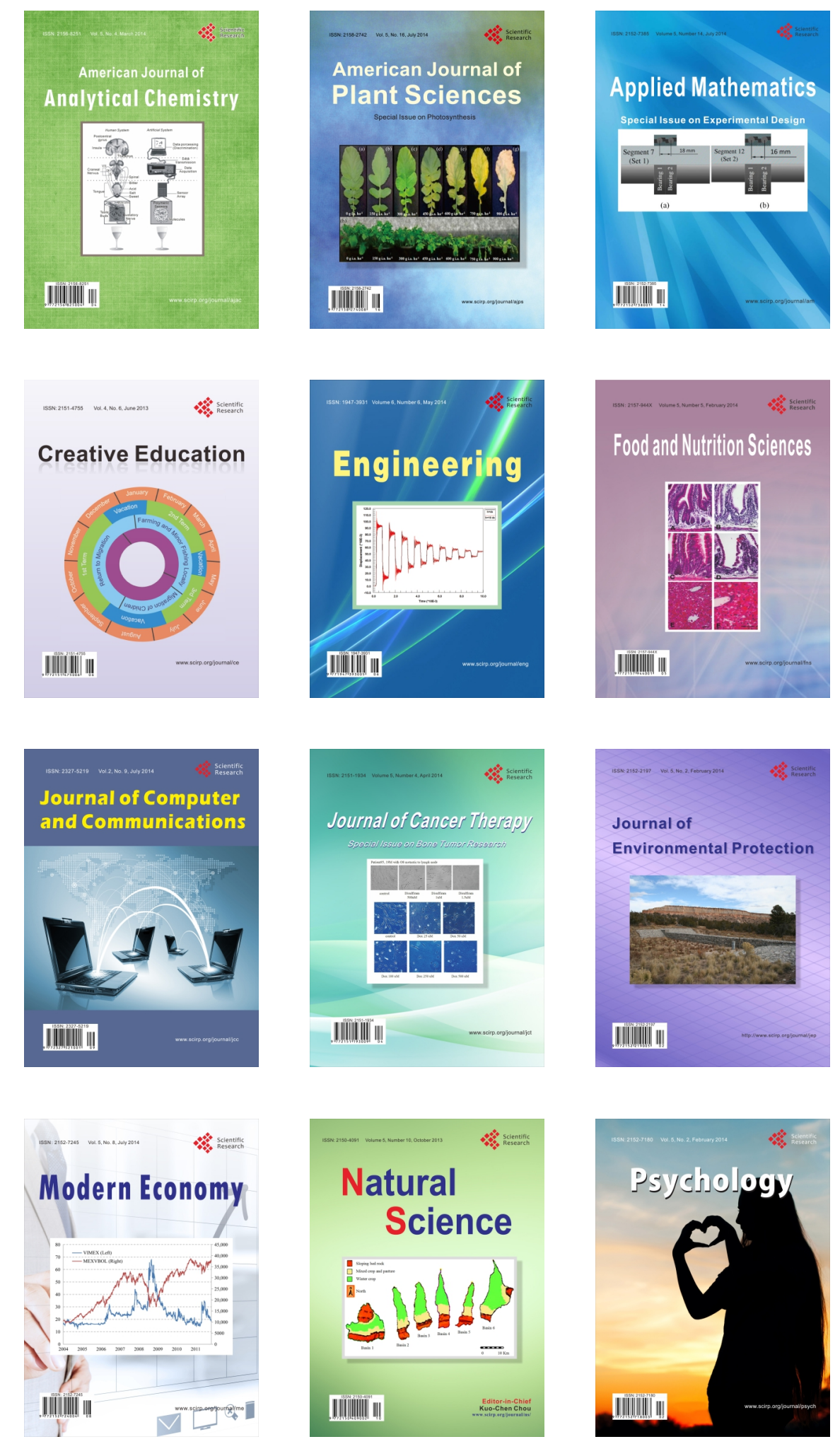